\title{
Transformation of Traditional Silvo-Pastoral Home-Gardens: A Case Study in Southern Sri Lanka
}

\author{
Mangala De Zoysa ${ }^{1}$ \\ ${ }^{1}$ Department of Agricultural Economics \& Extension, University of Ruhuna, Sri Lanka \\ Correspondence: Mangala De Zoysa, Department of Agricultural Economics \& Extension, Faculty of \\ Agriculture, University of Ruhuna, Mapalana, Kamburupitiya, 81100, Sri Lanka. Tel: 94-776-051-540. E-mail: \\ mangalaxyz@yahoo.com
}

Received: October 24, 2017 Accepted: November 10, 2017 Online Published: November 28, 2017

doi:10.5539/sar.v7n1p98 URL: https://doi.org/10.5539/sar.v7n1p98

\begin{abstract}
The Pasture Development Program on silvo-pastoral system in traditional home-gardens in Matara district was commenced with the aim of increasing milk production and income of the small-scale cattle farmers. The objectives of the study were to analyze ecosystem changes, economic trade-offs and social breakthroughs taken place in home-gardens after the program, with the aim of expanding the program coverage. The study was conducted through a field survey interviewing 34 farmers randomly selected from the participants. Tthe farmers have changed the composition of eco-systems in their home-gardens, replaced traditional grasses with $\mathrm{CO} 3$ fodder, and removed number of trees disturbing fodder cultivation. They have significantly lost some traditionally cultivated crops and trees due to competition with fodder during dry seasons. The farmers have significantly increased the milk yield per cow, market surplus and income, increased the amount of fodder sufficient to feed their cattle and little market surplus, and gradually adapted to cow-done as organic fertilizer. The social breakthroughs are identified as: reduced risk of conflicts with neighbors and theft of cattle, controlled damages caused by cattle to agricultural crops, reduced time spent on feeding cattle during dry seasons, increased domestic milk consumption, and increased the number of milk collecting centers induced by increased milk production. Although the Pasture Development Program have transformed the traditional home-gardens to improved silvo-pastoral system, community governance yet to be developed in order attract externalities particularly land use planning, technology development and policy support.
\end{abstract}

Keywords: silvo-pastoral system, traditional home-gardens, ecosystem changes, economic trade-offs, social breakthroughs

\section{Introduction}

According to the livestock statistics, the contribution milk production for national requirement is estimated at $33 \%$ in Sri Lanka in 2009 (Nanayakkara, 2013). The per capita consumption of milk and milk product in Sri Lanka is $3.5 \mathrm{~kg}$ /year, which is low compared to other South Asian countries (Perera \& Jayasooriya, 2008). Sri Lanka import milk powder spending around US\$ 400 million annually (Mendis and Edirisinghe, 2014). The present policy framework of Sri Lanka therefore aims at increase the national milk production and self-sufficient in milk in the medium term. The target of the government was to achieve 50 percent self-sufficiency in milk products by 2015. Smallholders dominate the local milk production systems in Sri Lanka operating by about 400,000 dairy farmers, at near-subsistence levels. About $73 \%$ of variable costs consist of feeds alone in dairy farming (Navaratne \& Buchenrieder, 2003). Limited access to good quality fodder year round is a major constraint to profitable smallholder dairy production. The main sources of concentrates used in dairy production in Sri Lanka are rice brand, coconut poonac and molasses, the by-products to supplement poor quality fodder basal diets (Department of Census and Statistics Sri Lanka, 2015). Cattles in Sri Lanka are primarily dependent on pasture and fodder found on neighbors' lands, roadsides and common areas (Ibrahim, et al., 1999). Creating conducive policy environment, the government has recognized the smallholder dairy farmers as the most important stakeholder in the domestic dairy industry and changed the land used policies particularly for pasture cultivation in favor of dairy development.

The Pasture Development Program in Matara district in Southern Sri Lanka commenced in 2012 with the aim of increasing milk production as well as income of the small-scale cattle farmers in short-term through continuous supply of sufficient quality feed. The average dairy farm has around 2-3 head of stock in Matara district are reared 
in small-scale operations based on proximity to markets and feed resources. Cattle are usually stall-fed, allowed to graze freely or tethered with mainly native pastures and crop residues. Presence of feed deficits is a major constraint to the dairy production systems in Matara district. The cattle depending on natural forages are facing severe shortage of green fodder availability particularly during the dry season. The pasture development program selected 10 small-scale cattle farmers who were rearing more than 2 cattle and can grow more than 200 bushes of fodder covering more than 10 perches $\left(1\right.$ perch $\left.=25.3 \mathrm{~m}^{2}\right)$ land in their home-gardens, from each 37 Veterinary Surgeons Ranges. Each year from 2012, around 100 farmers were given opportunities to join the program with the aim of completing in 4 years period. The traditional home-garden in Matara district is an intimate association of multipurpose trees and shrubs with annual and perennial crops and livestock. Rearing livestock in home-gardens in Sri Lanka is comparatively low but important for achieving long-term food and nutrition security (Marambe \& Silva, 2012). Home-gardens in Sri Lanka has a some form of cultivation in addition to the dwelling house on a total area of between 0.05 and 2.5 ha (mean 0.4 ha) (Pushpakumara et al., 2010). Home-gardens are mainly privately owned and have more secure rights and benefits from lands to land owners (De Zoysa \& Inoue, 2008). Home-gardens have been practiced for centuries as traditional life supporting systems (De Costa et al., 2006).

The home-garden provides ecosystem services, household needs and part of the household livelihood strategy (Weerahewa et al.., 2012). Forest Sector Master Plan of Sri Lanka in 1995 has identified the high potential of home-gardens for the promotion and sustain its multiple uses (MFE, 1995). The structure and management of a home garden varies from place to place, depending upon ecological, socio-economic and cultural factors. Rearing livestock in home-gardens in Sri Lanka is comparatively low and important for achieving long-term food and nutrition security (Marambe \& Silva, 2012).

The Provincial Council of the Southern Province invested Rs. 2.3 million in 2012 for the pasture development program. Each participant was given Rs. 5,000 as a grant in addition to the information leaflets, training, and CO3 fodder as planting materials. The Livestock Breeding Project in 1999 introduced Hybrid Napier var. CO-3 a high yielding perennial fodder as an efficient and economical solution to low productivity of national dairy herd in Sri Lanka (Premaratne \& Premalal, 2006). CO-3 grass prefers a deep fertile soil and grows well in high rainfall areas with optimum temperature ranging $25-40 \mathrm{C}^{0}$ in full sunlight as in Matara district. Hybrid Napier (Var. CO-3) fresh yields 5-8 kg / plant at 45 day cutting interval and 1 x $1 \mathrm{~m}$ spacing under good management. In view of the importance of feed resources as a major constraint to milk production, the analysis of impacts of the strategies of Pasture Development Program on silvo-pastoral system of home-gardens in Matara district to cope with feed constraints has become an urgent research need.

The objectives of the study were to examine the ecosystem changes, analyze the economic trade-offs and ascertain the social breakthroughs as impacts of the pasture development program on silvo-pastoral system of traditional home-gardens in Matara district. The study further made attempts to make policy implications in order to popularize and replicate in other districts as well.

\section{Method}

The study was conducted through a questionnaire survey interviewing 34 farmers randomly selected from 100 participants of the pasture development program in Matara district who had joined the program in 2012. The structural questionnaire was used in depth interviews of the survey was the primary source of data for the study. Further, discussion with key resource personnel of the program as well as field observation also facilitated for the collection of relevant primary data.

Descriptive statistics were calculated such as percent and frequency for categorical variables and mean with standard deviation, and median with range for continuous variables. Pearson's correlation was used to investigate the correlation between the variables. Wilcoxon Sign rank Test was used to identify the association between before and after the program situation of quantitative measurement. The Marginal Homogeneity Test was done to identify the association between before and after the program situation of qualitative measurements. The Kruskal-Wallis $\mathrm{H}$ test was used to determine if there are statistically significant differences between more groups of an independent variable on an ordinal dependent variable.

\section{Results and Discussion}

\subsection{The Milk Farmers Participating in Pasture Development Program}

The milk farmers participating in Pasture Development Program are mainly middle age (mean 47 and median 43 years) and having upper secondary education (mean $13^{\text {th }}$ and median $10^{\text {th }}$ Grade) (Table -1 ). They are having mostly the small size families (mean 3 and median 3 ) and possessing wide range in sizes from 40 to 320 perches 
(mean 128.7 and median 95 perches) of their home-gardens. The size and land ownership of home-gardens by all the farmers have favorable environment for their ability to grow $\mathrm{CO} 3$ quality fodder to feed their dairy cattle. Only $29 \%$ of them are full time farmers in occupation while others (71\%) are part-time farmers occupied in non-farm occupation. They are involving in the program for almost 4 years since 2012.

Table 1. General information of the milk farmers

\begin{tabular}{lccccc}
\hline & Minimum & Maximum & Mean & Std. Deviation & Median \\
\hline Age (Year) & 33 & 64 & 47 & 8.806 & 43 \\
Education (Grade) & 8 & 13 & 11 & 1.714 & 10 \\
Family Size (Number) & 2 & 5 & 3 & 0.913 & 3 \\
Home-garden Size (Perches) & 40.0 & 320.0 & 123.7 & 72.7 & 95 \\
\hline
\end{tabular}

Occupation Farming-10 (29); Government-5(15); Private-7(21); Self-Employ-12(35)

* Percentage in parentheses

\subsection{Ecosystem Changes in Silvopastoral System of the Home-Gardens}

Traditional composition of cattle has not been changed even after the implementation of pasture development program. The farmers are usually rearing Jersey, Persian, Syhivahal-cross and Syhivahal and Batu (indigenous) breeds in their home-gardens for generations. The number of cattle rearing under home-garden silvopastoral system has been changed in $39 \%$ significantly $(\mathrm{Z}=4.073$; and $\mathrm{P}=0.000)$ (Table -2$)$ after the program. The average number of cattle in a home-garden has been increased from 3 (Min-2; Max-5; SD-0.937) to 4 (Min-2; Max-8; SD-1.472). With the introduction of the pasture development program and increase of number of cattle, the farmers are experiencing in changed composition of eco-systems in their traditional home-gardens. Among the large number of different woody species, the majority of tree species found in home-gardens in Sri Lanka are indigenous or endemic with multi-purpose uses (Ariyadasa, 2002). The average total vegetation of the eco-system from the average total land in home-gardens has reduced by $07 \%$ with significantly change $(\mathrm{Z}=-4.369 ; \mathrm{P}=0.000)$ reducing from $82 \%$ (average 101 perches) to $76 \%$ (average 94 perches) after the implementation of the pasture development program. There are significant reductions of the coverage of all, Traditional grass/fodder in 66\% ( $\mathrm{Z}=-4.815$; and $\mathrm{P}=0.000)$; Annual Crops in $18 \%$ ( $\mathrm{Z}=-2.415$; and $\mathrm{P}=0.016$ ); Perennial Crops in 24\% ( $\mathrm{Z}=-4.617$; and $\mathrm{P}=0.000)$; Forest Trees in 05\% ( $\mathrm{Z}=-3.207$; and $\mathrm{P}=0.001)$; and Other Vegetation in $28 \%(\mathrm{Z}=-3.066$; and $\mathrm{P}=0.002)$ in the home-garden ecosystems. Households prefer to replace high canopy trees in their home-gardens with medium canopy cash crops and multipurpose trees to fulfill their basic needs (Pushpakumara et al., 2012).

The farmers have replaced traditional grasses and established the plots with $\mathrm{CO} 3$ fodder (Hybrid Napier Var.CO-3) using the planting materials distributed by the pasture development program. Technology adapted in home-gardens in Sri Lanka have changed over 55\% during the past twenty years (Daulagala, et al.., 2013). The farmers have reduced the average total land of their home-gardens under traditional grass/fodder from average 26 perches $(21 \%)$ to 9 perches (7\%). Instead, they have cultivated average 18 perches (16\%) in wide range of land extent (minimum - 10; maximum - 40) with introduced CO3 fodder, a high yielding fodder, based on the size of the home-gardens and their intention for the devotion in the program. There is a significant positive correlation $(\gamma=0.545 ; \mathrm{P}=0.001)$ between the size of the land used for $\mathrm{CO} 3$ fodder cultivation and the size of their home-gardens. The lands under coconut trees and forest tress particularly Teak in the home-gardens are commonly used for $\mathrm{CO} 3$ fodder as an under-cultivation. Those under-cultivations also provide grazing and cut and-carry $\mathrm{CO} 3$ forage for the dairy production. It could be observed that, with the development of silvopastoral system, only very few farmers have grown better quality trees mainly leguminous trees and bushes as complementary plants to make continuous access to feed the cattle and also benefit forest trees.

It could be observed that the farmers have removed number of trees disturbing fodder due to continuity of canopy cover, largely by the farmers having small-extent home-gardens. The vegetation of home-gardens of the milk farmers has lost average 9.88 perches (10\%) after the implementation of the pasture program. According to analysis, there is no significant correlation $(\gamma=0.184 ; \mathrm{P}=0.296)$ between the average size of home-gardens and the average size of lost vegetation. However, it could be observed that the farmers having small-extent home-gardens particularly have removed some individual trees, both perennial crops and forest trees which are shading their fodder plots. Moreover, according to the farmers, small-extent home-gardens have significantly lost some traditionally cultivated annual crops and perennial crops also due to competition with fodder during dry seasons, but remaining trees are growing vigorously. Higher organic matter incorporation in home-gardens enhance soil chemical and physical properties (Egodawatta et al., 2011). 
Table 2. Changes in the eco-systems of the home gardens after the pasture program

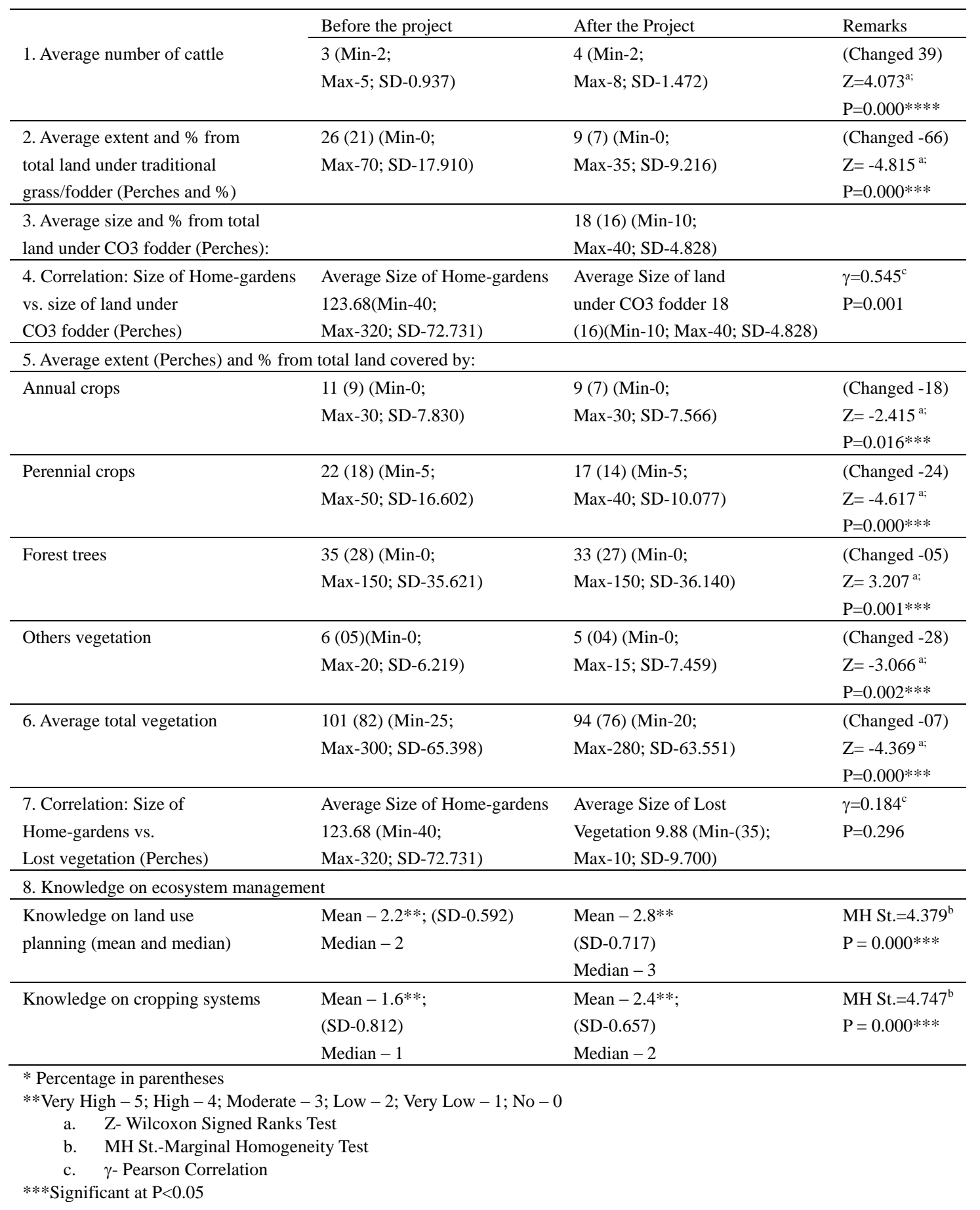

The knowledge of the farmers on ecosystem management in their home-gardens has not yet be improved even after the 4 years of implementing the pasture development program. The knowledge of the farmers on ecosystem management was measured in terms of knowledge on land use planning; and the knowledge on selecting cropping systems. At the inception of the program, the farmers have been trained by the officers on $\mathrm{CO} 3 \mathrm{fodder}$ cultivation in home-gardens in the view of improving their dairy farming. According to the farmers, their knowledge on land use planning of the home garden has been significantly changed $(\mathrm{MH} \mathrm{St}$. $=4.379$; and $\mathrm{P}=$ 0.000) only from the level of "Low" (mean - 2.2; minimum-1; maximum-3; SD-0.592 and median - 2) to "Moderate" (mean - 2.8; minimum-2; maximum-4; SD-0.717 and median - 3). Even the knowledge of majority of the farmers on selecting cropping systems for the home garden has been significantly changed $(\mathrm{MH}$ St. = 4.747; and $\mathrm{P}=0.000$ ), but only from the level of just "Very Low" (median - 1) to "Low" (median - 2) after 4 
years of the implementation of the program.

\subsection{Improvement of Economic Trade-Offs After the Pasture Development Program}

The pasture development program has significantly increased the milk yield per cow, market surplus and income as very important improvement of the economic trade-offs. The house-holds decisions on home-garden activities tends to be quite dynamic and management practices are mostly driven by their consumption and income generation needs (Galhena et al., 2012). The average production of milk per cow per day has increased by $90 \%$ significantly $(\mathrm{Z}=5.169$ and $\mathrm{P}=0.000)$ from 3.1 to 5.9 liters after the implementation of the pasture program (Table - 3). Similarly, the average amount of milk production per day per farmer has increased by $164 \%$ significantly $(\mathrm{Z}=5.169$ and $\mathrm{P}=0.000)$ from 9.6 to 25.2 liters (Table -3$)$. Households requires at least three upgraded cows to produce minimum of 15 liters of milk per day to earn a reasonable income from dairy farming (Ranaweera, 2007). They have increased the average amount of milk they sold in $177 \%$ significantly $(\mathrm{Z}=5.090$ and $\mathrm{P}=0.000)$ from 8.7 to 24.1 liters even after increasing the household consumption by $28 \%$ significantly $(Z=2.342$ and $\mathrm{P}=0.020)$ from 0.9 to 1.1 liters. The average income of a farmer has increased by $291 \%$ significantly $(\mathrm{Z}=5.086$ and $\mathrm{P}=0.000$ ) from Rs. 417.41 to 1629.79 per day also increasing the selling price of milk by $42 \%$ significantly $(\mathrm{Z}=5.093$ and $\mathrm{P}=0.000)$ from average Rs. 46.97 to 66.82 per liter. The average daily income of a farmer after the participating in the program has wide range from minimum Rs. 469 to maximum Rs. 4,340 (SD-913.910). Since most of the farmers (71\%) are part-time farmers, they consider this income as an extra earning for the household. Even the full-time farmers (29\%) do milk farming in their home-gardens as an additional domestic activity with the help of wife and the other family members.

Table 3. Change of economic trade-offs of the milk farmers after the pasture program

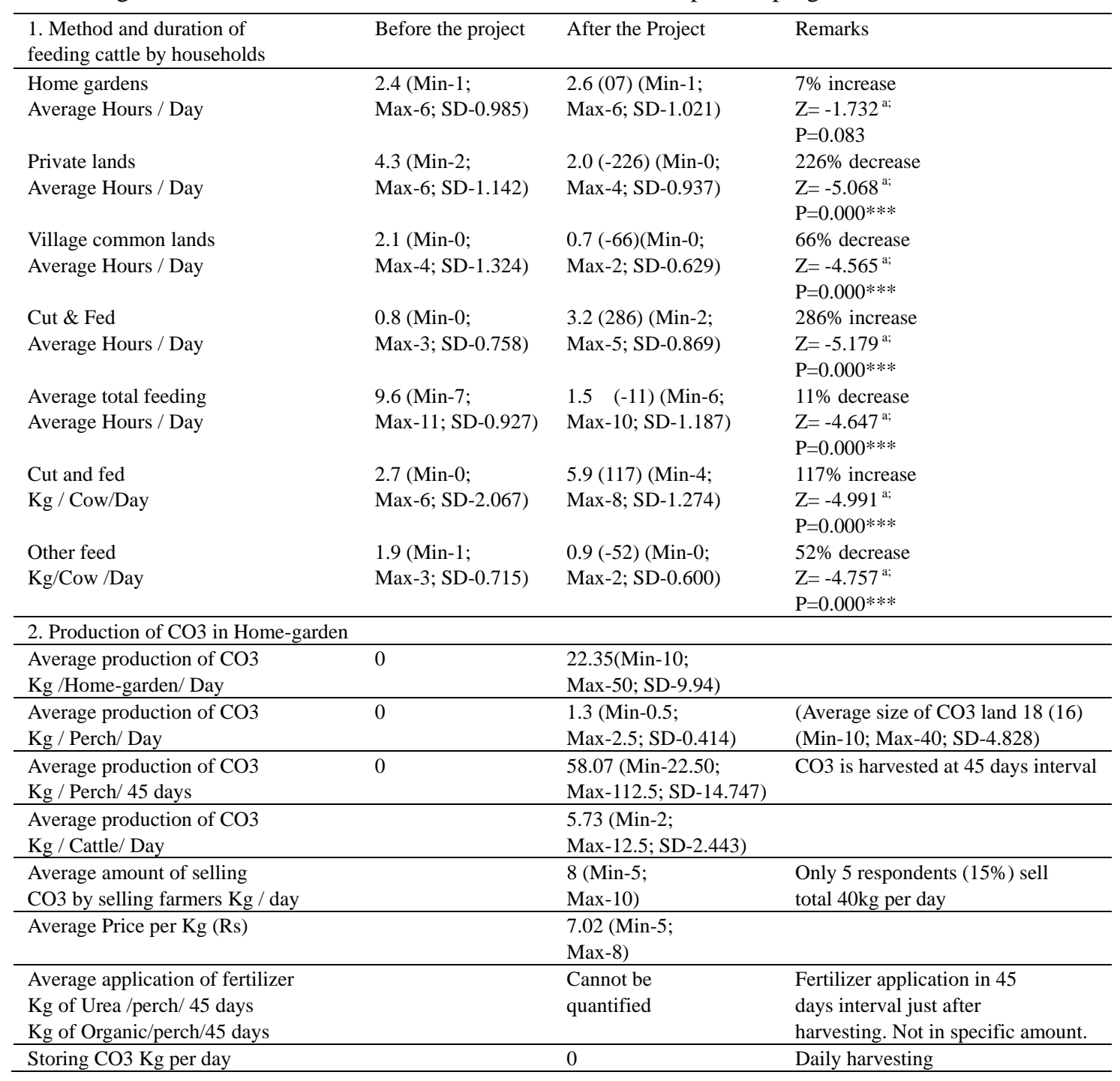




\begin{tabular}{|c|c|c|c|}
\hline $\begin{array}{l}\text { 3. Production, consumption, selling of and } \\
\text { income from milk for farmers from } \\
\text { home-gardens }\end{array}$ & Before the project & After the Project & Remarks \\
\hline $\begin{array}{l}\text { Average production } \\
\text { of milk Liters / Cow / Day }\end{array}$ & $\begin{array}{l}3.1(\text { Min-2; } \\
\text { Max-5; SD-0.830) }\end{array}$ & $\begin{array}{l}5.9(90)(\text { Min-4; } \\
\text { Max-8; SD-1.200) }\end{array}$ & $\begin{array}{l}90 \% \text { increase } \\
\mathrm{Z}=5.169^{\mathrm{a}} \\
\mathrm{P}=0.000^{* * *}\end{array}$ \\
\hline $\begin{array}{l}\text { Average amount of } \\
\text { milk production } \\
\text { Lit /Day / Farmer }\end{array}$ & $\begin{array}{l}9.6(\operatorname{Min}-4 ; \\
\text { Max-25; SD-5.052) }\end{array}$ & $\begin{array}{l}25.2(164)(\text { Min-8; } \\
\text { Max-64; SD-12.966) }\end{array}$ & $\begin{array}{l}164 \% \\
\text { increase } \\
\mathrm{Z}=5.090^{\mathrm{a}} \\
\mathrm{P}=0.000 * * *\end{array}$ \\
\hline $\begin{array}{l}\text { Average amount of } \\
\text { milk consumption } \\
\text { Lit / Day / Farmer family }\end{array}$ & $\begin{array}{l}0.9(\text { Min- } 0 \\
\text { Max-2; SD-0.610) }\end{array}$ & $\begin{array}{l}1.1(28)(\text { Min-0; } \\
\text { Max-3; SD-0.537) }\end{array}$ & $\begin{array}{l}28 \% \text { increase } \\
\mathrm{Z}=2.324^{\mathrm{a}} \\
\mathrm{P}=0.020^{* * *}\end{array}$ \\
\hline $\begin{array}{l}\text { Average amount } \\
\text { of milk sold } \\
\text { Lit / Day /Farmer }\end{array}$ & $\begin{array}{l}8.7(\operatorname{Min}-3 ; \\
\text { Max-25; SD-5.132) }\end{array}$ & $\begin{array}{l}24.1(177)(\text { Min-7; } \\
\text { Max-62; SD-12.869) }\end{array}$ & $\begin{array}{l}177 \% \\
\text { increase } \\
\mathrm{Z}=5.090^{\mathrm{a} ;} \\
\mathrm{P}=0.000 * * *\end{array}$ \\
\hline $\begin{array}{l}\text { Average amount of milk } \\
\text { sold to neighbors } \\
\text { Lit / Day /Farmer }\end{array}$ & $\begin{array}{l}\text { 0.7(Min-0; } \\
\text { Max-3; SD-0.836) }\end{array}$ & $\begin{array}{l}1.8(150) \\
(\text { Min-0; } \\
\text { Max-6; SD-1.499) }\end{array}$ & $\begin{array}{l}150 \% \\
\text { increase } \\
Z=4.406^{a ;} \\
P=0.000 * * *\end{array}$ \\
\hline $\begin{array}{l}\text { Average Price of } \\
\text { milk received Rs /Lit }\end{array}$ & $\begin{array}{l}46.97 \text { (Min-40; } \\
\text { Max-52; SD-3.167) }\end{array}$ & $\begin{array}{l}66.82(42)(\text { Min-60; } \\
\text { Max-70; SD-2.724) }\end{array}$ & $\begin{array}{l}42 \% \text { increase } \\
\mathrm{Z}=5.093^{\mathrm{a}} \\
\mathrm{P}=0.000 * * *\end{array}$ \\
\hline $\begin{array}{l}\text { Average Income } \\
\text { from milk Rs/day/ Farmer }\end{array}$ & $\begin{array}{l}417.41(\text { Min-120; } \\
\text { Max-1300; SD-262.908) }\end{array}$ & $\begin{array}{l}1629.79(291)(\text { Min-469; } \\
\text { Max-4340; SD-913.910) }\end{array}$ & $\begin{array}{l}291 \% \\
\text { increase } \\
\mathrm{Z}=5.086^{\mathrm{a}} \\
\mathrm{P}=0.000^{* * *}\end{array}$ \\
\hline $\begin{array}{l}\text { 4. Correlation: Amount of milk production } \\
\text { (Lit/Day/Farmer) vs. Production of CO3 }(\mathrm{Kg} \\
\text { /Home-garden/ Day) after the program }\end{array}$ & $\begin{array}{llr}\text { Average amount of } \text { milk } \\
\text { production }(\text { Lit/Day/Farmer) } & 9.6 \\
(\text { Min-4; Max-25; SD-5.052) } & \\
\end{array}$ & $\begin{array}{l}\text { Average production of CO3 (Kg } \\
\text { /Home-garden/Day) } 22.35 \text { (Min-10; } \\
\text { Max-50; SD-9.94) }\end{array}$ & $\begin{array}{l}\gamma=0.580^{c} \\
P=0.000\end{array}$ \\
\hline $\begin{array}{l}\text { 5. Correlation: Amount of milk production } \\
\text { (Lit/Day/Farmer) vs. Production of CO3 }(\mathrm{Kg} \\
\text { /Home-garden/ Day) after the program }\end{array}$ & $\begin{array}{l}\text { Average amount of milk } \\
\text { production (Lit/Day/ Farmer) } 9.6 \\
(\text { Min-4; Max-25; SD-5.052) } \\
\end{array}$ & $\begin{array}{l}\text { Average size of home-garden } \\
\text { (Perches) } 123.68 \text { (Min-40; Max-320; } \\
\text { SD-72.731) }\end{array}$ & $\begin{array}{l}\gamma=0.663^{c} \\
P=0.000\end{array}$ \\
\hline \multicolumn{4}{|l|}{$\begin{array}{l}\text { 6. Contribution of vegetable, fruit, fire-wood } \\
\text { and wood from home-gardens }\end{array}$} \\
\hline $\begin{array}{l}\text { Average } \% \text { of vegetable contribution from } \\
\text { home-garden for farmer household } \\
\text { consumption }\end{array}$ & $\begin{array}{l}20.1(\operatorname{Min} 0 ; \\
\operatorname{Max}-40 ; \text { SD-13.285) }\end{array}$ & $\begin{array}{l}12.1(-40)(\text { Min-0; } \\
\text { Max-30; SD-10.381) }\end{array}$ & $\begin{array}{l}\text { 40\% decrease } \\
\mathrm{Z}=-4.231^{\mathrm{a}} \\
\mathrm{P}=0.000 * * *\end{array}$ \\
\hline $\begin{array}{l}\text { Average } \% \text { of fruits contribution from } \\
\text { home-garden for farmer household } \\
\text { consumption }\end{array}$ & $\begin{array}{l}57.4(\text { Min-10; } \\
\text { Max-90; SD-17.111) }\end{array}$ & $\begin{array}{l}35.4(-38)(\text { Min-0; } \\
\text { Max-80; SD-17.511) }\end{array}$ & $\begin{array}{l}38 \% \text { decrease } \\
\mathrm{Z}=-5.098^{\mathrm{a}} \\
\mathrm{P}=0.000 * * *\end{array}$ \\
\hline $\begin{array}{l}\text { Average } \% \text { of fire wood contribution } \\
\text { from home-garden for farmer } \\
\text { household consumption }\end{array}$ & 100 & 100 & \\
\hline $\begin{array}{l}\text { Average } \% \text { of wood contribution } \\
\text { from home-garden for } \\
\text { farmer household consumption }\end{array}$ & $\begin{array}{l}63.5(\operatorname{Min}-0 ; \\
\text { Max-95; SD-19.288) }\end{array}$ & $\begin{array}{l}62.8(-01)(\text { Min-0; } \\
\text { Max-95; SD-19.196) }\end{array}$ & $\begin{array}{l}01 \% \text { decrease } \\
\mathrm{Z}=-1.890^{\mathrm{a}} \\
\mathrm{P}=0.059\end{array}$ \\
\hline
\end{tabular}

* Percentage in parentheses
a. Z-Wilcoxon Signed Ranks Test
b. MH St.-Marginal Homogeneity Test
c. $\gamma$-Pearson Correlation
$* * *$ Significant at $\mathrm{P}<0.05$

The farmers have increased the production of fodder at in their home-gardens sufficient to feed their cattle and little market surplus after the implementation of pasture development program. Further to grazing at home-gardens, private lands and village common lands, the average amount of fodder used for cut and fed the cattle has been increased by $117 \%$ significantly $(\mathrm{Z}=4.991$ and $\mathrm{P}=0.000)$ from 2.7 to $5.9 \mathrm{~kg}$ per cow per day after the implementation of the pasture program. The pasture program has taken enough effort to produce average $5.73 \mathrm{~kg}$ of $\mathrm{CO} 3$ per cow per day with minimum $2 \mathrm{~kg}$ to maximum $12.5 \mathrm{~kg}$ (SD-2.443). They harvest CO3 daily based on the requirement of their cattle to keep the palatability of the cattle with fresh fodder. The farmers produce average $58.07 \mathrm{~kg}$ (minimum 22.50; maximum 112.5; SD-14.747) of $\mathrm{CO} 3$ per perch in 45 days production / harvesting cycle. The increase of fodder production due to the pasture development program has influenced the farmers to reduce the amount of feeding cattle with other feeds mainly rice straw and rice brand 
by $52 \%$ significantly ( $\mathrm{Z}=-4.757$ and $\mathrm{P}=0.000$ ) from 1.9 to $0.9 \mathrm{~kg}$ per cow per day. More than $50 \%$ of the rice straw, a major crop residue in Sri Lanka is used as animal feed (Perera, 1992). There are 70-90,000 tons of rice bran produced annually in Sri Lanka is one of the main sources of concentrates used in dairy production to supplement the poor quality fodder basal diets (Ibrahim, et. al, 1999). The farmers purchase Rice Brand at the rate of Rs 25 / kg, and Cattle Feed (Gawa Ahaara) at Rs. 950/25 kg (Bag) and some Minerals to feed their cattle. The Rice Straw is available in the village paddy fields of their fellow farmers and collect free of charge to feed the cattle.

Although there is an increase of pasture production in home-gardens, the average duration of feeding the cattle per day at home-garden has not increased significantly $(7 \%, \mathrm{Z}=1.732$ and $\mathrm{P}=0.083)$. However, the average feeding duration of cattle at private lands has decreased in $226 \%$ significantly $(\mathrm{Z}=-5.068$ and $\mathrm{P}=0.000)$ from 4.3 to 2.0 hours per day after the pasture program. The average duration of feeding at the village common land also has reduced in $66 \%$ significantly $(\mathrm{Z}=-4.565$ and $\mathrm{P}=0.000)$ from 2.1 to 0.7 hours per day after the pasture program. The average total duration of feeding the cattle also has reduced in $11 \%$ significantly ( $\mathrm{Z}=-4.647$ and $\mathrm{P}=0.000$ ) from 9.6 to 8.6 hours per day after the pasture program. Moreover, the amount of milk production per day per farmer after the pasture program, has a significant positive correlation $(\gamma=0.580 ; \mathrm{P}=0.000)$ with the amount of the production of $\mathrm{CO} 3$ fodder per day per farmers. Similarly, the amount of milk production per day per farmer also has a significant positive correlation $(\gamma=0.663 ; \mathrm{P}=0.000)$ with the production of $\mathrm{CO} 3$ per home-garden per day after the program. It could be revealed that only very few $(15 \% ; 5$ respondents) farmers sell average $8 \mathrm{~kg}$ (minimum 5; maximum 10) of $\mathrm{CO} 3$ per day at the average price of Rs. 7.02 per kg. As the formal milk buyers, MILCO purchase milk at the fixed rate of Rs. 70 /liter and Lucky Yogurt Rs. 65 /liter from the farmers. The purchasing price is vary by the local milk collectors.

The increased volume of cow done with the increased volume of feeding fodder has replaced the inorganic fertilizer application in $\mathrm{CO} 3$ plots. Hybrid Napier grass produced higher yield with adequate organic manure than applied with inorganic fertilizer (Jayanthi, 2003). According to the farmers, they have gradually adapted to cow-done as organic manure replacing urea used for fodder, crops and trees. With the implementation of the pasture program, each farmer was given Rs. 5,000 as an incentive without considering their extent of CO3 fodder cultivation or the size of their home-garden. Some of them have applied Urea to their CO3 plots without any standard amount but depend on availability after applying the fertilizer to their paddy fields. However, it could be observed that almost all the farmers are usually collecting and applying cow don as organic manure not only to their agricultural crops but also to the $\mathrm{CO} 3$ fodder plots in their home gardens.

Contribution of vegetables and fruits from home-gardens in daily diet has been reduced but negligible compared to the increased income from milk production. Most of the farmers (79\%) have produced average $20.1 \%$ (minimum 0; maximum 40; SD-13.285) of their daily house hold requirements of vegetables in their home gardens before the pasture program. After the implementation of the pasture, $68 \%$ of the farmers have reduced the daily household vegetable contribution in $40 \%$ significantly ( $\mathrm{Z}=-4.231$ and $\mathrm{P}=0.000$ ) to $12.1 \%$ (minimum 0; maximum 30; SD-10.381). Similarly, all the farmers (100\%) have produced average 57.4\% (minimum1 0; maximum 90; SD-17.111) of daily household fruits requirement before the implementation of the program. Home-gardens in Sri Lanka constitute the most significant fruits production system (Weerakkody, 2004). The contribution of the average daily household fruit requirement of $97 \%$ of the farmers, from the home-garden has reduced by $38 \%$ significantly $(\mathrm{Z}=-5.098$ and $\mathrm{P}=0.000)$ to average $35.4 \%$ (minimum0; maximum 80 ; $\mathrm{SD}-17.511$ ) after the pasture development program. However, all the farmers (100) fulfill the $100 \%$ of their fire-wood requirement totally from their home-gardens even after the implementation of the pasture program. The very little $(01 \%)$ reduction of average home-garden contribution of household wood requirement of $97 \%$ farmers from 63.5\% with wide range (minimum 0; maximum 95; SD-19.288) to 62.8\% (minimum 0; maximum 95; SD-19.196) after the implementation of the program is not statistically significant. Home-gardens supply more than $70 \%$ of the timber and more than $80 \%$ of the fuel-wood requirement in the country (Chokkalingam \& Vanniarachchy, 2011).

\subsection{Development of Social Breakthroughs by the Pasture Development Program}

The pasture program has facilitated the control of damages caused by cattle to the agricultural crops in farmers own home-gardens to some extent but the home-gardens of their neighboring households at considerable level. The reduction of average damage (from Mean 1.9 to 1.7) done by the grazing of cattle in home garden is not significant $(\mathrm{MH} \mathrm{St} .=0.870 ; \mathrm{P}=0.384)$ and still the majority is remaining at "Low" level (Median -2$)($ Table 4). However, the damage done in neighbors' home-gardens has reduced (from Mean 1.1 to 0.3) to the level of almost "No" (Median -0$)$ significantly $(\mathrm{MH} \mathrm{St.}=4.439 ; \mathrm{P}=0.000)$ after the pasture program. The pasture development program has reduced the conflicts with neighbors and risk of theft of cattle by increasing cutting 
and feeding cattle without allowing long duration grazing in private (from 4.3 to 2.0 hours per day) and common lands (from 2.1 to 0.7 hours per day). The average conflicts with neighbors due to gracing of cattle also have reduced (from Mean 0.7 to 0.1 ) significantly $(\mathrm{MH} \mathrm{St} .=4.146 ; \mathrm{P}=0.000)$ to the level of "No". The risk of the theft of cattle has also reduced from "Low" to "Very Low" (from Mean 1.9 to 0.8 ) significantly (MH St. = 4.503; $\mathrm{P}=0.000)$ after the pasture development program.

Table 4. Social breakthroughs of the milk farmers after the pasture development program

\begin{tabular}{|c|c|c|c|}
\hline $\begin{array}{l}\text { 1. Average cattle damage to } \\
\text { agricultural crops (Mean and Median) }\end{array}$ & Before the project & After the Project & Remarks \\
\hline Own & $\begin{array}{l}\text { Mean-1.9**; (SD-0.702) } \\
\text { Median-2 }\end{array}$ & $\begin{array}{l}\text { Mean-1.7** } \\
(\mathrm{SD}-0.760) \\
\text { Median-2 }\end{array}$ & $\begin{array}{l}\text { MH St. }=0.870^{\mathrm{b}} \\
\mathrm{P}=0.384\end{array}$ \\
\hline Neighbor & $\begin{array}{l}\text { Mean-1.1**; (SD-0.712) } \\
\text { Median-1 }\end{array}$ & $\begin{array}{l}\text { Mean-0.3**; (SD-0.524) } \\
\text { Median-0 }\end{array}$ & $\begin{array}{l}\text { MH St. }=4.439^{\mathrm{b}} \\
\mathrm{P}=0.000^{* * *}\end{array}$ \\
\hline $\begin{array}{l}\text { 1. Average conflict with neighbor on } \\
\text { gracing (Mean and Median) }\end{array}$ & $\begin{array}{l}\text { Mean-0.7**; (SD-0.589) } \\
\text { Median-1 }\end{array}$ & $\begin{array}{l}\text { Mean-0.1**; (SD-0.327) } \\
\text { Median-0 }\end{array}$ & $\begin{array}{l}\text { MH St. }=4.146^{\mathrm{b}} \\
\mathrm{P}=0.000^{*} * *\end{array}$ \\
\hline 2. Average risk of theft of the cow & $\begin{array}{l}\text { Mean-1.9**; } \\
(\text { SD-1.525702) } \\
\text { Median-2 }\end{array}$ & $\begin{array}{l}\text { Mean-0.8**; (SD-0.855) } \\
\text { Median-1 }\end{array}$ & $\begin{array}{l}\text { MH St. }=4.503^{b} \\
\mathrm{P}=0.000^{* * *}\end{array}$ \\
\hline $\begin{array}{l}\text { 3. Average Family members involving } \\
\text { in feeding }\end{array}$ & 1 & 1 & $\begin{array}{l}\text { Mainly husband involving in } \\
\text { feeding. Wife also support }\end{array}$ \\
\hline $\begin{array}{l}\text { 4. Average time spend on feed } \\
\text { collecting and stall feeding Hours } \\
\text { (Mean and Median) }\end{array}$ & $\begin{array}{l}\text { Mean-4.1**; (SD-1.647) } \\
\text { Median-4 }\end{array}$ & $\begin{array}{l}\text { Mean-2.3**; (SD-0.963) } \\
\text { Median-2 }\end{array}$ & $\begin{array}{l}\text { MH St. }=5.127^{\mathrm{b}} \\
\mathrm{P}=0.000^{*} * *\end{array}$ \\
\hline $\begin{array}{l}\text { 5. Average time spend on moving } \\
\text { cattle for grazing Hours (Mean and } \\
\text { Median) }\end{array}$ & $\begin{array}{l}\text { Mean-2.2**; (SD-0.819) } \\
\text { Median-2 }\end{array}$ & $\begin{array}{l}\text { Mean-2.0**; (SD-0.758) } \\
\text { Median-2 }\end{array}$ & $\begin{array}{l}\text { MH St. }=2.111^{\mathrm{b}} \\
\mathrm{P}=0.035^{* * *}\end{array}$ \\
\hline 6. No. of milk collectors / centers & 2 & 5 & $\begin{array}{l}\text { Milco, Lucky Yogurt, } 3 \text { informal } \\
\text { collectors }\end{array}$ \\
\hline $\begin{array}{l}\text { 7. Average convenience of milk selling } \\
\text { (Mean and Median) }\end{array}$ & $\begin{array}{l}\text { Mean-2.0**; (SD-0.603) } \\
\text { Median-2 }\end{array}$ & $\begin{array}{l}\text { Mean-4.0**; (SD-1.058) } \\
\text { Median-4 }\end{array}$ & $\begin{array}{l}\text { MH St. }=5.417^{\mathrm{b}} \\
\mathrm{P}=0.000^{* * *}\end{array}$ \\
\hline $\begin{array}{l}\text { 8. Average amount of domestic milk } \\
\text { consumption Lit / Day / Farmer } \\
\text { family }\end{array}$ & $\begin{array}{l}0.9 \\
\text { (Min-0; Max-2; SD-0.610) }\end{array}$ & $\begin{array}{l}1.1(28) \\
\text { (Min-0; Max-3; SD-0.537) }\end{array}$ & $\begin{array}{l}28 \% \text { increase } \\
\mathrm{Z}=2.324^{\mathrm{a} ;} \\
\mathrm{P}=0.020^{* * *}\end{array}$ \\
\hline $\begin{array}{l}\text { 9. Average amount of milk sold to } \\
\text { neighbors Lit / Day /Farmer }\end{array}$ & $\begin{array}{l}0.7 \\
\text { (Min-0; Max-3; SD-0.836) }\end{array}$ & $\begin{array}{l}1.8(150) \\
(\text { Min-0; Max-6; SD-1.499) }\end{array}$ & $\begin{array}{l}150 \% \text { increase } \\
\mathrm{Z}=4.406^{\mathrm{a}} \\
\mathrm{P}=0.000^{* * *}\end{array}$ \\
\hline $\begin{array}{l}\text { 10. Organizing milk farmers (Mean } \\
\text { and Median) }\end{array}$ & $\begin{array}{l}\text { Mean-0.6**; (SD-0.597) } \\
\text { Median-1 }\end{array}$ & $\begin{array}{l}\text { Mean-1.5**; (SD-0.896) } \\
\text { Median-2 }\end{array}$ & $\begin{array}{l}\text { MH St. }=4.427^{\mathrm{b}} \\
\mathrm{P}=0.000^{* * *}\end{array}$ \\
\hline $\begin{array}{l}\text { 11. Interest of farmers in further } \\
\text { promotion of dairy farming }\end{array}$ & & $\begin{array}{l}\text { Mean-4.2**; (SD-0.834) } \\
\text { Median-4 }\end{array}$ & \\
\hline 12. Requirements for promotion & & & $\begin{array}{l}\text { Kruskal Wallis Test: Grouping } \\
\text { Variable: Interest (Range } 3 \sim 5 \text { ) }\end{array}$ \\
\hline More funds & & $\begin{array}{l}\text { Mean-4.1**; (SD-0.821) } \\
\text { Median-4 }\end{array}$ & $\begin{array}{l}\mathrm{KW}=8.462^{\mathrm{d}} \\
\mathrm{P}=0.015^{* * *}\end{array}$ \\
\hline Shade tolerance fodder & & $\begin{array}{l}\text { Mean-3.9**; (SD-0.729) } \\
\text { Median-4 }\end{array}$ & $\begin{array}{l}\mathrm{KW}=8.337^{\mathrm{d}} \\
\mathrm{P}=0.015^{* * *} *\end{array}$ \\
\hline Low priced fodder cutter & & $\begin{array}{l}\text { Mean-2.1**; (SD-1.013) } \\
\text { Median-2 }\end{array}$ & $\begin{array}{l}K W=0.416^{d} \\
P=0.812\end{array}$ \\
\hline Improved cattle breed & & $\begin{array}{l}\text { Mean-3.4**; (SD-0.981) } \\
\text { Median-3 }\end{array}$ & $\begin{array}{l}K W=0.045^{d} \\
P=0.978\end{array}$ \\
\hline Better Price for milk & & $\begin{array}{l}\text { Mean-4.4**; (SD-0.652) } \\
\text { Median-4 }\end{array}$ & $\begin{array}{l}\mathrm{KW}=8.174^{\mathrm{d}} \\
\mathrm{P}=0.017^{* * *}\end{array}$ \\
\hline Subsidy for cattle shed & & $\begin{array}{l}\text { Mean-2.6**; (SD-1.252) } \\
\text { Median-2 }\end{array}$ & $\begin{array}{l}K W=0.473^{d} \\
P=0.789\end{array}$ \\
\hline
\end{tabular}

* Percentage in parentheses

**Very High-5; High-4; Moderate-3; Low-2; Very Low-1; No-0

a. Z- Wilcoxon Signed Ranks Test

b. MH St.-Marginal Homogeneity Test

c. $\gamma$-Pearson Correlation

d. KW-Kruskal Wallis Test

****Significant at $\mathrm{P}<0.05$

The farmers have reduced the time they spent on feeding cattle by collecting grasses and fodder from different 
sources available in the village, particularly during dry seasons. The dairy farmers in wet zone including Matara district spend average 3.7 hours daily on dairy activities mainly feeding the animals; either collecting fodder or taking animals to and from tethered grazing (Ibrahim, et. al, 1999). In all the households, farmers are directly involving in feed collecting and feeding their cattle with the support of their elderly sons. House wives of the farmers do milking as a traditional practice in additional to their household activities. All the farmers have to cut the fodder in the morning and feed the cattle. The part-time farmers $(71 \%)$ who are engaging in non-farm occupations have to cut the fodder in the afternoon and request a family member mainly the wife to feed the cattle. Lack of labor availability is the main reason for the low level of management in home-gardens, because family members are involved in other jobs (Jayawardena \& Jayatilaka, 1998). They feel that the average time they spend on feed collecting and stall feeding has significantly reduced $(\mathrm{MH} \mathrm{St} .=-5.127 ; \mathrm{P}=0.000)$ from "High" to "Low" (from Mean 4.1 to 2.3) after the production of $\mathrm{CO} 3$ fodder in their home-gardens.

Increased domestic milk consumption by farmers' as well as their neighboring families is also an important social breakthrough of the pasture development program leading to eradication of rural malnutrition. Home-gardens in Sri Lanka are user-driven and produce multiple benefits of direct relevance for local livelihoods (Mattsson et al., 2013). The consumers perceive milk powder as an inferior good thus the demand is likely to shift increasingly to liquid milk is the current trend in Sri Lanka. The government also is making effort organizing awareness programs to popularize the liquid milk consumption. The average amount of domestic milk consumption of the farmers has increased in $28 \%$ significantly $(\mathrm{Z}=2.324 ; \mathrm{P}=0.020)$ from 0.9 to 1.1 liter per family per day after the pasture development program. Their neighboring families also have increased their milk consumption in $150 \%$ significantly $(\mathrm{Z}=4.406 ; \mathrm{P}=0.000)$ from average 0.7 to 1.8 liter per family per day.

The farmers have understood that the increased number of government and private milk collecting centers have been induced by the increased milk production after the pasture development program. According to the farmers, the average number of milk collectors has been increased from 2 to 5 joining 3 trustworthy informal collectors in addition to the government own MILCO and the private own Lucky Yogurt. The informal market is critical to profitability for the small holding producers for their liquid milk and making the dairying an economically viable enterprise. The informal market consists of sales directly to individual consumers, and private milk collectors who then sell milk either to collection centers, restaurants, local manufacturers of milk products or to consumers. Presently, however, the farmers are experiencing the increase of convenience of milk selling from "Low" to "High" (from Mean 2.0 to 4.0). Increased price paid for milk along with an improved collection network encouraged dairy farmers to produce more milk (Ranaweera, 2009).

The farmers have not yet promoted community governance in order attract externalities to promote their dairy farming in home-gardens even after the successfully implementing the pasture development program. The number and total area of home-gardens in Sri Lanka have been increasing annually over the years with little policy support (Pushpakumara et al., 2012). Although the organizing of milk farmers has been significantly increased (MH St. $=4.427^{;} \mathrm{P}=0.000$ ) from Mean 0.6 to 1.5 , the majority of them feel that are still remaining at "Low" (Median-2) level. Their knowledge on ecosystem management particularly the knowledge on land use planning (Mean-2.8) and knowledge on cropping system (Mean-2.4) are at "Low" and "Moderate" levels respectively even more than 4 years after the implementation of the pasture program (Table -2). It could be revealed that the farmers are "Highly" (Mean-4.2; Median-4) interested in further promotion of their dairy farming. Village households utilize home-gardens as a local strategy addressing the issue of dairy farming even with limited resources and institutional support (Galhena, et al., 2013). Considering the interest "Range from 3 to 5" (Moderate to Very High) of the farmers for the promotion of their dairy farming, the farmers have "High" and significant requirement of: more funds (Mean-4.1 and Median-4; $\mathrm{KW}=8.462 ; \mathrm{P}=0.015$ ), shade tolerance fodder variety (Mean-3.9 and Median-4; KW = 8.337; $\mathrm{P}=0.015$ ) and better price for their milk (Mean-4.4 and Median-4; KW $=8.174 ; \mathrm{P}=0.017$ ). The officials of the pasture development program have already started adaptive research programs with shade tolerant fodder varieties with the view of replacing $\mathrm{CO} 3$ fodder for home-gardens. The farmers have "Low" (Mean-2.1 and Median- 2) requirement of low priced fodder cutter but not significant $(\mathrm{KW}=0.416 ; \mathrm{P}=0.812)$ with interest as the grouping variable. Higher average production of milk is obtained due to better nutrition provided under cut and fed system (Ranaweera, 2007). The farmers have a "Moderate" (Mean-3.4 and Median-3) requirement of improved cow breeds which is not significant (KW = 0.045; P = 0.978) with their interest. According to Mendis \& Edirisinghe (2014), the technology mainly new breeds, breeding techniques and training programs on animal husbandry significantly aid for the growth of domestic fresh milk supply. Similarly, they have almost "Moderate" (Mean-2.6 and Median-2) requirement of subsidy for a cattle shed, but not significant $(\mathrm{KW}=0.473 ; \mathrm{P}=0.789)$ with their interest in further improvement of dairy farming in their home-gardens. 


\section{Conclusions and Policy Implications}

The pasture development program in Matara district has created some considerable changes in ecosystem in home-gardens, and has contributed very important economic trade-offs and social breakthroughs. It is recommended to design sustainable silvo-pasture system with appropriate land use system based on the size and composition of their home-gardens. Developing and popularizing fodder resources among small cattle farmers requires strengthen institutional support particularly for the research and extension. The farmers have not yet promoted community governance in order attract externalities particularly land use planning, selection of cropping systems, technology development to introduce high yielding shade tolerance food and policy support even after the successfully implementing the pasture development program. There is not only the nutrition but also the quality of animals need for the improvement of productive efficiency in the medium term. Establish of farmer organization will empower the farmers and encourage them for collective efforts to improve standards of their dairy farming. Further improvement and expansion of the pasture development program may promote domestic liquid milk consumption particularly in rural households and will have strong positive effects on opportunities for domestic milk production thus increasing fodder production in home-gardens for feeding the cattle.

\section{References}

Ariyadasa, K. P. (2002). Assessment of tree resources in the home-gardens of Sri Lanka. Bangkok, ECFAO Partnership Program on Information and Analysis for Sustainable Forest Management (FAO, 2005).

Chokkalingam, U., \& Vanniarachchy. S. A. (2011). Sri Lanka's REDD potential: Myth or reality? Forest carbon Asia country Profile Report No. 1: Sri Lanka. Forest Carbon Asia. Retrieved November 10, 2017, from http://www.forestcarbonasia.org/wp-content/uploads/2010/10/Sri-Lanka-Country-Report-final-23.05.2011.p df.

Daulagala, C., Weerahewa, J., Marambe, B., Pushpakumara, G., Silva, P., Punyawardena, R., Premalal, S., Miah, G., Roy, J., \& Jana, S. (2013) .Socio - Economic Characteristics of Farmers Influencing Adaptation to Climate Change: Empirical Results from Selected Homegardens in South Asia with Emphasis on Commercial Orientation. Sri Lanka Journal of Advanced Social Studies, 2(2), 71-90. https://doi.org/10.4038/sljass.v2i2.6208

De Costa, W. A. J. M., Amaratunga, K. S. P., \& Udumullage, R. S. (2006). Transpiration characteristics of some home-garden tree species in central Sri Lanka. In: Tropical home-gardens: a time tested example of sustainable agroforestry, ed. Kumar, E.D and P.K.R. Nair, 377 pp. Dordrecht: Springer.

De Zoysa, M., \& Inoue, M. (2008). Forest governance and community based forest management in Sri Lanka: Past, present and future perspectives. International Journal of Social Forestry, 1, 27-49.

Department of Census and Statistics Sri Lanka (2015), Department of census and statistics Sri Lanka. paddy statistics. http://www.statistics.gov.lk/agriculture/Paddy\%20Statistics/PaddyStats.htm

Egodawatta, W. C. P., Sangakkara, U. R., Wijesinghe, D. B., \& Stamp, P. (2011). Impact of green manure on productivity patterns of home-gardens and fields in a tropical dry climate. Tropical Agricultural Research, 22(2), 172-182. https://doi.org/10.4038/tar.v22i2.2826

Galhena, D. H., Freed, R., \& Maredia, K. M. (2013). Home gardens: A promising approach to enhance household food security and wellbeing. Agriculture and Food Security, 2(1), 8. https://doi.org/10.1186/2048-7010-2-8

Ibrahim, M. N. M., Staal, S. J., Daniel, S. L. A. \& Thorpe, W. (1999). Appraisal of the Sri Lanka dairy sector. Volume 1: Synthesis Report. Ministry of Livestock Development and Estate Infrastructure, Colombo, Sri Lanka.

Jayanthi, C. (2003) Productivity of Bajra-Napier hybrid grass under different planting methods and time of fertilizer applications. htpp://www.tnau.ac.in/scms/agronomy/jayanthi.htm.

Jayawardena, L. N. A. C., \& Jayatilaka, M. W. A. P. (1998). Role of gender in the optimum use of Kandyan forest gardens as a source to food to meet food security requirements. In: Multipurpose Tree Species in Sri Lanka-Fuelwood Energy and Gender Issues. Eds. H. P. M. Gunasena, D. K. N. G. Pushpakumara, B. Marambe, S.P. Nissanka and I.P. Wickramasinghe. pp. 47-60. Proceedings of the Ninth National Workshop on Multipurpose Trees, December 3-5, 1998. Kandy, Sri Lanka.

Marambe, B., \& Silva, P. (2012). Sustainability management in agriculture - a systems approach. In: Handbook of Sustainability Management. Chapter 33. Eds. C. N. Madu \& Kuei, C. H. pp. 687-712. World Scientific 
Publishers Company, Singapore. https://doi.org/10.1142/9789814354820_0033

Mattsson, E., Ostwald, M., Nissanka, S. P., \& Marambe, B. (2013). Homegardens as a Multi-functional Land-Use Strategy in Sri Lanka with Focus on Carbon Sequestration; AMBIO, 42, 892-902. https://doi.org/10.1007/s13280-013-0390-x

Mendis, S. S., \& Edirisinghe, J. C. (2014). Milk Powder Imports and Government Policy: The Case of Sri Lanka. Journal of Agriculture Economics and Rural Development, 2(3), 86-91. https://doi.org/10.12966/jaerd.08.03.2014

Ministry of Forestry and Environment (1995). Sri Lanka forestry sector master plan. Forestry Planning Unit, Ministry of Forestry and Environment, Battaramulla, Sri Lanka, 512 pp.

Nanayakkara, P. (2013). 'Liquid milk: on the path to self-sufficiency', business today, 2013.05, Retrieved April 28, 2017, from http://www.businesstoday.lk/cover_page.php?issue $=262$

Navaratne, M. A. J. S., \& Buchenrieder, G. (2003). Economics of Small-Scale Dairy Farming in Sri Lanka - A Case Study from Coconut Cattle Silvo Pastoral System. Proceedings, "Technological and Institutional Innovations for Sustainable Rural Development”, Deutscher Tropentag, October 8-10, 2003, G"ottingen, Germany

Perera, A. N. F. (1992). Agricultural by-products as a feed source for ruminants. In: Poceedings of workshop on eco-friendly commercial activities. MOF and NORAD, 8 December, 1992, BMICH, Colombo, Sri Lanka, $8-15$.

Perera, B., \& Jayasuriya, M., (2008). The dairy industry in Sri Lanka: current status and future directions for a greater role in national development. Journal of the National Science Foundation of Sri Lanka, 36, 115-126. https://doi.org/10.4038/jnsfsr.v36i0.8050

Premaratne, S., \& Premalal, G. G. C. (2006). Hybrid Napier (Pennisetum perpureum X Pennisetum americarnum) var. CO-3: a resourceful fodder grass for dairy development in Sri Lanka; The Journal of Agricultural Sciences, 2(1). https://doi.org/10.4038/jas.v2i1.8110

Pushpakumara, D. K. N. G., Marambe, B., Silva G. L. L. P., Weerahewa, J., \& Punyawardena, B. V. R. (2012). Tropical Agriculturist, 160, 55-125

Pushpakumara, D. K. N. G., Wijesekara, A., \& Hunter, D. G. (2010). Kandyan home-gardens: A promising land management system in Sri Lanka. In Sustainable use of biological diversity in socio-ecological production landscapes, ed. C. Belair, Ichikawa, K., Wong, B. Y. L. \& Mulongoy, K. J. 102-108. Background to the 'Satoyama Initiative for the benefit of biodiversity and human well-being. Secretariat of the Convention on Biological Diversity, Montreal, Canada.

Ranaweera N. F. C., (2009). 'Sri Lanka: Opportunities for dairy sector growth', Smallholder dairy development: Lessons learned in Asia, http://www.fao.org/docrep/011/i0588e/I0588E08.htm

Ranaweera, N. F. C. (2007) Improved Market Access and Smallholder Dairy Farmer Participation for Sustainable Dairy Development. Lessons Learned Sri Lanka. FAO Report. 5-21. http://www.s3.amazonaws.com/zanran_storage/www.aphca.org/ContentPages/45037639.pdf

Weerahewa, J., Pushpakumara, G. Silva, P., Daulagala, C., Punyawardena, R., Premalal, S., Miah, G., Roy, J., Jana, S., \& Marambe, B. (2012). Are home garden ecosystems resilient to climate change? An analysis of the adaptation strategies of home gardeners in Sri Lanka. APN Science Bulletin, 2, 22-27.

Weerakkody, W. A. P. (2004). Horticulture in Sri Lanka. Chronica Horticulturae, 44, $23-27$.

\section{Copyrights}

Copyright for this article is retained by the author(s), with first publication rights granted to the journal.

This is an open-access article distributed under the terms and conditions of the Creative Commons Attribution license (http://creativecommons.org/licenses/by/3.0/). 